\title{
What motivates medical students to select medical studies: a systematic literature review
}

\author{
Sonu Goel ${ }^{1 *}$, Federica Angeli, ${ }^{2,3}$, Nonita Dhirar ${ }^{1}$, Neetu Singla ${ }^{1}$ and Dirk Ruwaard ${ }^{4}$
}

\begin{abstract}
Background: There is a significant shortage of health workers across and within countries. It is of utmost importance to determine the factors that motivate students to opt for medical studies. The objective of this study is to group and review all the studies that investigated the motivational factors that underpin students' selection of medical study in recent years.

Methods: The literature search was carried out by two researchers independently in PubMed, Google Scholar, Wiley and IndMED databases for articles published from year 2006 till 2016. A total of 38 combinations of MeSH words were used for search purpose. Studies related to medical students and interns have been included. The application of inclusion and exclusion criteria and PRISMA guidelines for reporting systematic review led to the final selection of 24 articles.

Results: The majority of the studies ( $n=16 ; 66.6 \%)$ were from high-income countries followed by an equal number from upper-middle and lower-middle income countries $(n=4,16.7 \%)$. None of the studies were from low-income countries. All of the studies were cross-sectional in nature. The main motivating factors that emerged were scientific (interest in science / medicine, social interest and academia, flexible work hours and work independence), societal (prestige, job security, financial security) and humanitarian (serving the poor and under priviledged) in high-, upper-middle and lower-middle income countries, respectively. The findings were comparable to Maslow's hierarchy of needs theory of motivation.

Conclusion: This systematic review identifies the motivational factors influencing students to join medical studies in different parts of the globe. These factors vary per country depending on the level of income. This study offers cues to policy makers and educators to formulate policy in order to tackle the shortage of health workers, i.e. medical doctors. However, more research is needed to translate health policy into concrete and effective measures.
\end{abstract}

Keywords: Motivation, Medical students, Rural areas, Systematic review

\section{Background}

The world is currently facing a dual problem of shortage and inequitable distribution of health workers, especially in middle- and low-income countries [1]. The World Health Organization (WHO) estimated a need for an additional 4.3 million health workers in 57 countries to fulfill the Millennium Development Goals [2]. In addition, 83 countries (44.6\%) do not currently meet the 2006 World Health Report threshold of 22.8 skilled health professionals per 10,000 population [3]. Among many, the main reasons cited for shortage of health workers in rural areas

\footnotetext{
* Correspondence: sonugoel007@yahoo.co.in

'School of Public Health, PGIMER, Sector-12, Chandigarh 160012, India

Full list of author information is available at the end of the article
}

include poor working conditions, lack of accommodation, lack of transport, poor pay structure, overburden with additional administrative responsibility and political interference [4]. In middle- and low-income countries, the situation is more critical because of migration of doctors to high-income (developed) countries whereas inequitable distribution of health workers between urban and rural areas is primarily due to poor motivation of health workers to work in rural areas [5].

The choice of medical study depends upon various factors such as interest in the medical field, good job opportunities, a desire to serve others, medical background of the parents and many more [6, 7]. In literature, no review has been conducted in the last ten years about motivation 
factors of students to select medical studies. The existing reviews have either been conducted before ten years or with different objectives $[8,9]$. One review by Puertas et al. [8] published in 2013 was conducted to review the factors influencing medical student's choice in primary care while another one by Brissette and Howes [9] published in 2010 was conducted on the articles available till 2008. Brisstte and Howes identified that motivation to take up medical studies lies in addressing learner's needs for competence, autonomy, and relatedness. Providing optimal challenge and positive performance feedback, choice and opportunity for self-direction, and a sense of belongingness and connection to the medical profession can all be focused on to address the above mentioned motivators [9]. The review has given points for educators to act upon.The lacunae left by the previous review studies need to be addressed in a finer manner in context with the current challenge of the global workforce.

In last few years, human resources for health has attracted substantial scholarly attention. Over the last decade, there have been advancement in different fields of medical sciences, from prevention, patient care to laboratory workup and management of severe diseases and palliation. With the growing population and improving health care owing to better technologies, it is gravely important to improve the medical workforce, mostly doctors.

Globally, several health-related goals and programs are giving priority to human resource development in the health sector. The major health related initiatives like Sustainable Development Goals [10] and WHO's six building blocks [11] focus on human resource development for achieving universal health coverage. The National health programs, like the National Health Mission in India, focuses on increasing human resources to upbring the health care services in the country.

The prospective medical students form a significant pool of health care workers that can help overcome the shortage globally. Therefore, understanding the current common motivational factors is essential and a summary of the factors through a review of these studies would derive a clearer picture. A strong predictor for any student to take up a career in any field is the motivation or drive from within. Motivation is defined as the process that initiates, guides, and maintains goal-oriented behaviors. It involves the biological, emotional, social, and cognitive forces that activate behavior. Fulfillment of needs results in some type of behavior, which can be either intrinsic or extrinsic [7]. Understanding motivation is very important in the medical sector because a motivated individual is willing to exert and maintain an effort to provide goodquality health services.

The objective of this study is to group and review all the studies that investigated the motivational factors that underpin students' selection of medical study in recent years.

\section{Methods}

\section{Search strategy}

The literature search was carried out with the purpose to identify the perceptions of medical students to enter medical studies. The search was carried out by two researchers (NS and ND) independently in PubMed, Google Scholar, Wiley and IndMED databases for original studies conducted from 2006 to 2016. This time frame was chosen as many studies were done during this period to identify the motivational factors. MeSH and free-text terms "(Motivat*) AND (select* OR choice OR choose) AND (medical student* OR medical school* OR interns) have been used. Internship in the period of practical application of theoretical (mostly) knowledge of the previous medical school years, hence interns were also made a part of the search strategy. Search terms and keywords were altered as per specification of individual databases. A total of 38 combinations were used for search purpose.

An initial search identified thousands of related records from the Google scholar, PubMed, Ind Med and Wiley online library databases. The articles which were not related to motivation were excluded at the first step. Then search results were imported to Microsoft Excel and duplications were removed by sorting the titles of articles. The selected studies were then screened by reading the title and abstract resulting in shortlisting 91 articles. Of these, 62 articles were excluded based on eligibility criteria. The remaining 29 full-text articles were further assessed, and five were excluded because the articles were in Korean, Spanish and Chinese. A total of 24 studies were selected. Any differences of opinion were debated and consensus was reached. Further differences were resolved by the third researcher (SG). PRISMA guidelines were strictly followed during the study. Figure 1 represents the flow chart leading to sample selection.

\section{Selection criteria and sample}

All studies carried out and published from year 2006 till 2016 were included in the review. Inclusion criteria were studies describing motivation to study medicine, conducted among medical students and interns and available in English language. Exclusion criteria were those studies done before 2006, published in languages other than English, and those not related to motivation or medical students and interns.

\section{Data analysis}

A thematic analysis of selected papers was performed, wherein two research assistants coded the papers independently and reached consensus on relevant themes [12]. They also extracted details of the final articles using a standardized abstraction form that collected information on: the author, the journal, the year of publication, location, study objectives, study 

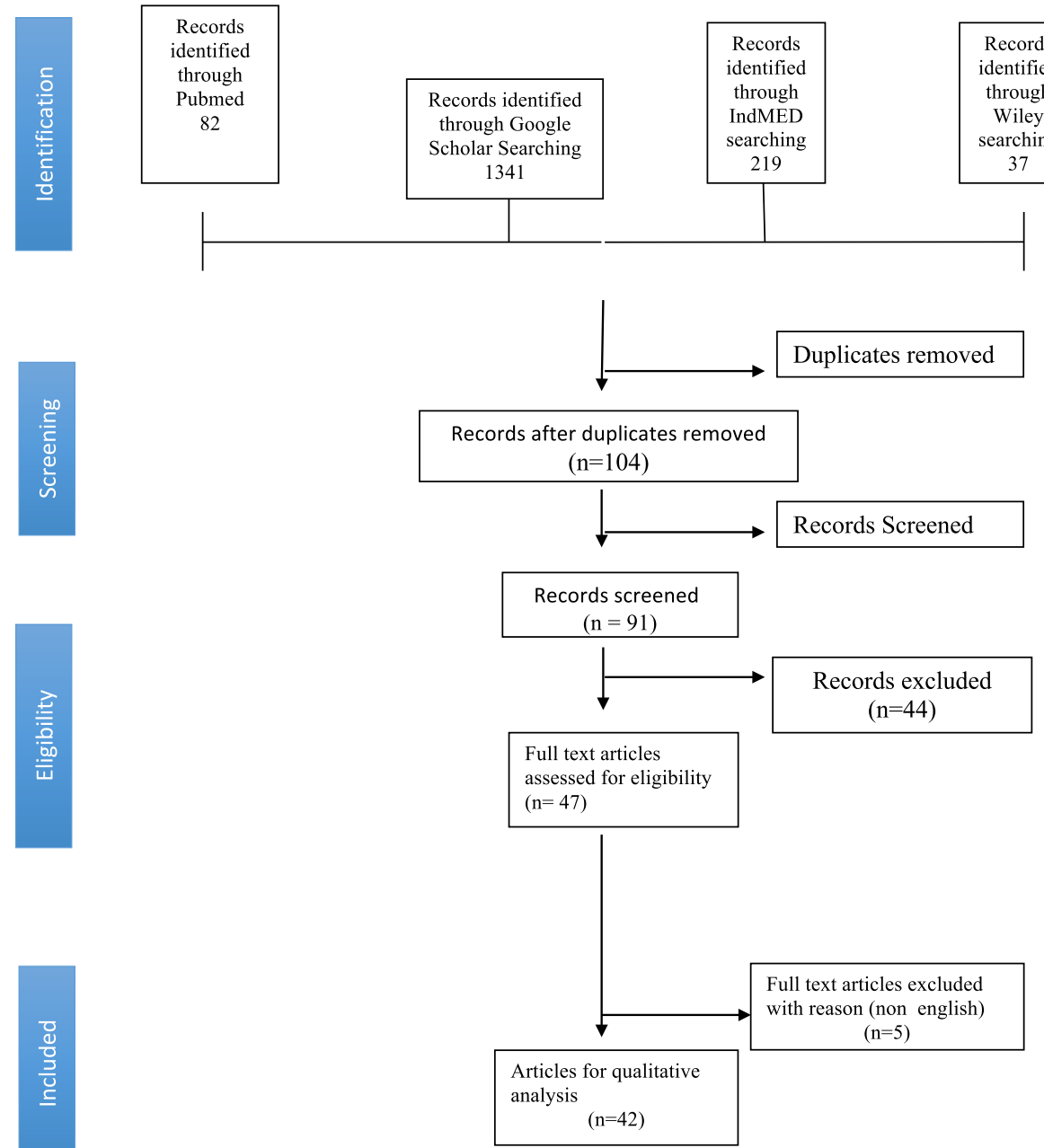

Fig. 1 Flow chart of selection and exclusion of studies for the systematic review

design, major findings, limitations, and observations. In this paper, we systematically review the literature related to medical education with the goal of identifying the motivating factors influencing the medical students to join medical studies.

The results of the studies' review were categorized under different heads viz. scientific factors, social factors and humanitarian factors based upon criteria devised by Goel $\mathrm{S}$ et al. in their study on development and validation of the motivations for selection of medical study in India [13]. In this study a 'Motivation of Selection of Medical Study (MSMS)' tool was developed using extensive literature review followed by Delphi technique. The three domains and the issues that emerged are shown in Table 1.

\section{Ethical considerations}

The study was granted ethical approval from the Institute's Ethical Committee, PGIMER, Chandigarh (PGI/ IEC/2012/810-1 P-154). Since the study is a systematic review of studies and individual level data is neither obtained nor presented, the consent.

\section{Results}

The characteristics of the studies included in the systematic review are shown in Table 2. The assessment of factors of motivations for medical students to select medical studies was based on the World Bank categorization of low-, middle- and high-income countries [14].The lowincome, lower middle-income, upper middle-income and high-income economies are defined as those with a Gross National Income (GNI) per capita of $\$ 1005$ or less, between \$1006 and \$3955, between \$3956 and \$12,235 and $\$ 12,236$ or more, respectively in the year 2016 . The majority of the studies $(n=16,66.6 \%)$ were from high-income countries followed by an equal number from upper middle and lower middle income countries $(n=4,16.7 \%)$. None of the studies were from low-income countries. All of the studies were cross sectional in nature $(n=24)$. Figure 2 shows the geographic distribution of the different studies. 
Table 1 Domains and issues that emerge as main motivational factors

\begin{tabular}{ll}
\hline Domains & Issues \\
\hline Scientific & - Ability to use new cutting edge technologies \\
& - Interest in medicine as a subject matter \\
& - Opportunities to travel and work internationally \\
& - Research opportunities \\
& - Loss of a loved one \\
Societal & - Job security \\
& - Social status/prestige \\
& - High income \\
& - Proposed by parents \\
Humanitarian & - Desire to help others \\
& - Desire to give back to their home community or \\
& country \\
\hline
\end{tabular}

Predominance of motivating factors according to income group

Results reported for motivation to select medicine by medical students changes in the context of place (see Fig. 3 and Table 3). The choice of medical study among students differs between students in high-income countries, and those in upper-middle and lower-middle-income countries. The individual motivation factors that emerged are presented in Table 4.

\section{High-income countries}

In most of the high-income counties, scientific and humanitarian factors were described as the main motivators to select medicine by medical students [15-29]. Most of the high income countries including Spain, Croatia, Poland, UK, Hungary, Germany and South Korea reported similar type of motivators to motivate the medical students for choosing medicine: interest in science/medicine, social interest, flexible work hours and work independence. Results reported by Kim et al.(2016) [16], Becker et al. (2015) [29], Wouters (2014) [19] emphasized on the scientific factors. Societal factors were also reported in most of these studies but fell lower in hierarchy.

Table 2 Characteristics of the studies included in the systematic review $(n=24)$

\begin{tabular}{ll}
\hline Characteristic & Number (\%) \\
\hline Income Group & $16(66.6)$ \\
- high-income countries & $4(16.7)$ \\
- upper-middle income countries & $4(16.7)$ \\
Study design & \\
- cross sectional studies & $24(100 \%)$ \\
Study type & \\
- quantitative & $21(87.5)$ \\
- qualitative & $1(4.2)$ \\
- mixed methods & $2(8.3)$ \\
\hline
\end{tabular}

\section{Uppermiddle income countries}

The main motivators to select medicine by medical students of upper-middle income countries include the societal and scientific factors [30-33]. A study by Kavousipour et al. (2015) [30] conducted in Iran explains that the factors which were most significant to motivate the students were family attitudes, getting good jobs in future, respect for themselves, the ability to learn, believing their role in victory and defeat and the tendency toward optimism about themselves. Pagnin et al. (2013) [32] also concluded similar findings. Social and professional status of the job, healthcare-people factor, others' recommendation and advices, personal interest and nature of occupation, occupational experience and personal life had been identified as main factors of motivation. The findings reported by Korkmaz et al. (2013) [31] also found societal and scientific factors to be more significant motivators.

\section{Lower-middle -income}

In low-middle income countries, students have mixed responses for the choice of medical studies. [34-37]. Humanitarian and societal factors had been reported as main influences to join medicine.

Few studies conducted in various parts of India had reported almost similar results. A study conducted in Madhya Pradesh, India by Diwan et al. (2013) [35] concluded that reasons for entering medical education included personal ambition, parental desire, prestigious profession, altruistic reasons and pecuniary incentives. Similar to these findings were those reported by Kuriakose (2015) [34], Seetharaman et al. (2012) [36] and Lal et al. in 2007 [37]. The main reasons that motivate the medical students were to serve the sick and society and having a high status in society.

\section{Discussion}

To our knowledge, this is the first systematic review of motivational factors for choosing medical studies by medical students globally. Earlier reviews were related to factors influencing student rating in undergraduate medical education course evaluations and factors that influence a career choice in primary care among medical students from high-, middle- and low-income countries [8]. The present systematic review, which has analyzed 24. studies in detail, is important as it identifies the motivational factors influencing the medical students to join medical studies in different parts of the globe along with the variations among the factors in lower-middle, uppermiddle and high-income countries. As such, it provides essential insights into how students could be motivated, and how this varies across countries. No study was found from low-income countries. The limited research on this topic in low-income countries could be related to the lack of interest in this particular area, or to an 


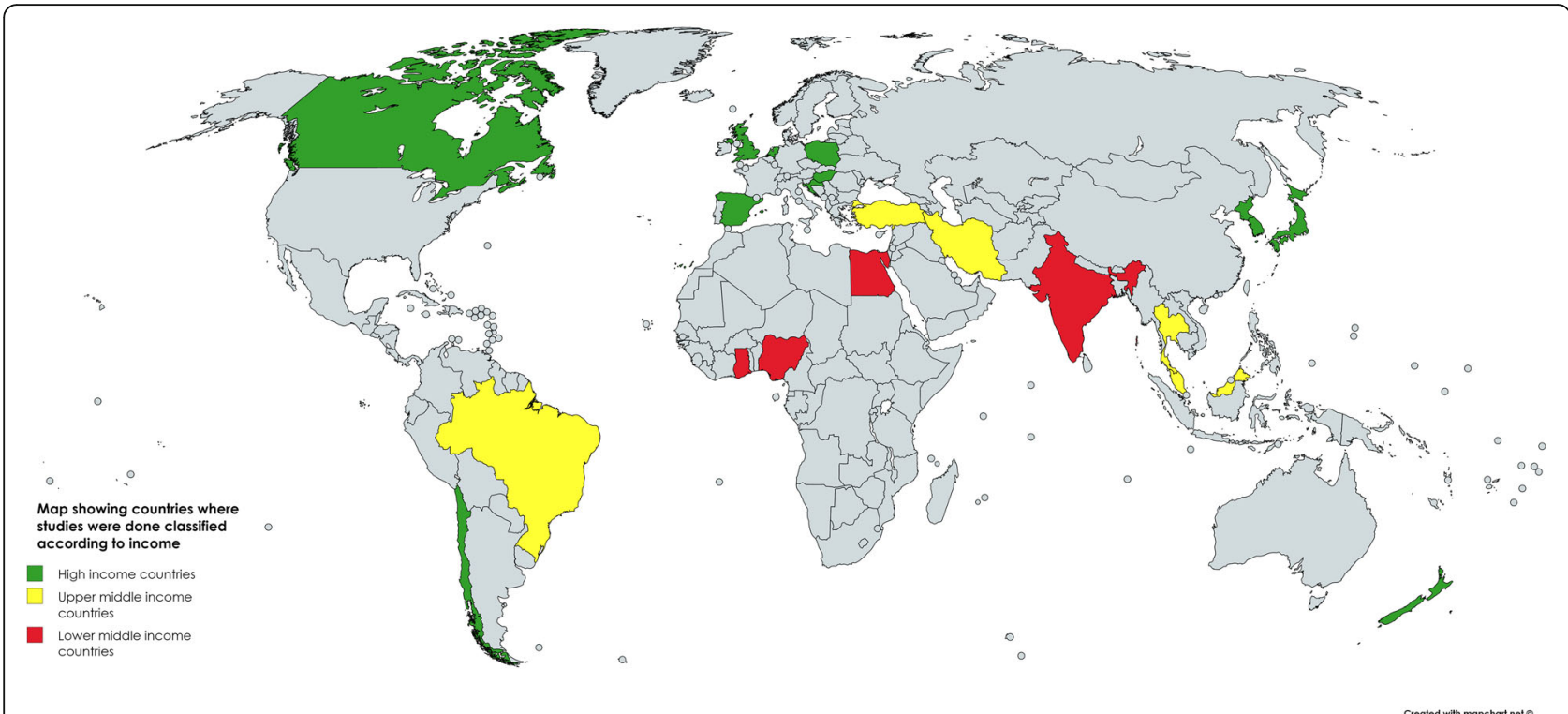

Fig. 2 Geographical distribution of the different studies across the globe (used a web page https://mapchart.net which is free of cost and specifically designed for making customised maps)

overall deficit in research in developing nations, or both. These countries could identify the issues and intervene according to the research done in lower-middle and upper-middle income countries.

Several theories of motivation have been described in relation to career choice among student including intrinsic and extrinsic factors as described by Brissette and Howe [9] and by Maslow [38],. Taylor, McClelland and Herzberg [39]. However, Maslow's theory remains to be the most detailed and frequently used theory [38]. The Maslow's hierarchy of needs describes motivational factors under five broad segments: the physiological needs, the needs for safety and security, the needs for love and belonging, the needs for esteem, and the need to actualize the self, in that order [38].
Physiological needs are the basic needs required by an individual, such as food, water, sleep, etc. Once these needs are met, the second segment of needs comes into picture making safety, stability, protection the prime concerns. Following these factors the third segment consists of desires to marry, have a family, become a part of their community etc. The fourth segment of esteem has two versions as described by Maslow. The need for respect, prestige, prominence, magnificence, appreciation, attention, status, self-esteem, and dominance forms the lower version while the higher form involves the need for self-respect which includes feelings as self-confidence, capability, accomplishment, mastery, and freedom. The last segment is the phase of selfactualization which is a desire for self-fulfillment [38].

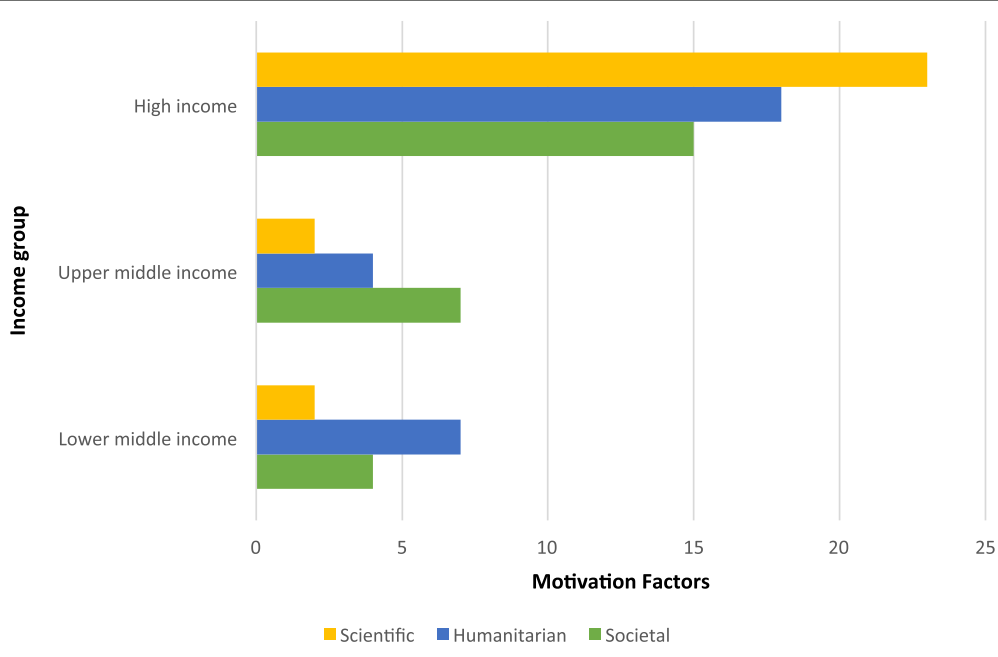

Fig. 3 Categorization of motivation factors across different income country groups 
Table 3 Factors affecting motivations of medical students to select medicine across different country income groups

S. No Name of the study Name of author Year Type of study $\quad$ Place of No. of Factors Individual factors

study participants categorization

High Income Countries

1. Career motivation and burnout among medical students in Hungary could altruism be a protection factor?

2. Differences in medical students' academic interest and performance across career choice motivations

3. Motivation towards medical career choice and future career plans of Polish medical students.

4. Why medicine? Analyzing students' motives for studying medicine

5. Studying medicine $-\mathrm{a}$ cross-sectional questionnaire-based analysis of the motivational factors which influence graduate and undergraduate entrants in Ireland

6. A qualitative analysis of statements on motivation of applicants for medical school

7. Applicants to the University of Adelaide Medical School: Influences, motivation and alternative career choices

8. Interests and perspectives of first and last year medical students

9. The medical career choice motivationresults from Hungarian study

10. Effects of age, gender and educational background on strength of motivation for medical school

11. Motivation, study habits, Amin Z and expectations of medical students in Singapore

Gyorffy Z et al. $\quad 2016 \begin{aligned} & \text { Cross- } \\ & \text { Sectional } \\ & \text { Quantitative }\end{aligned}$

Kim KJ et al.
2016 Cross - Sectional Quantitative
South
Korea

Gąsiorowski J et al. 2015 CrossSectional Quantitative

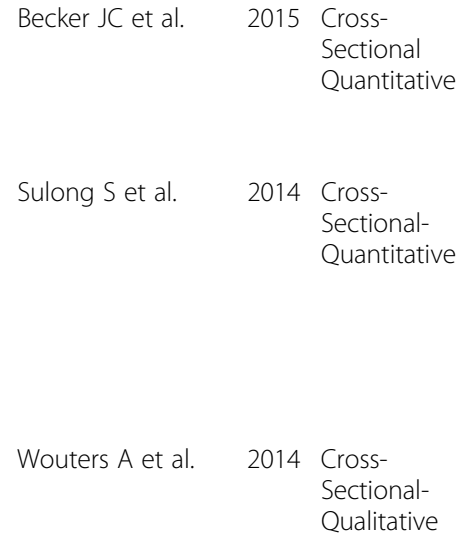

Wouters A et al.
2014 Cross-
Sectional-
Qualitative

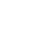

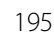

95

(1)

Poland

262

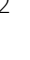

Germany 1545

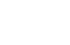
Laurence CM et al. 2013 Cross- Sectional Quantitative

Australia 1097

Toso A et al.

$2012 \begin{aligned} & \text { Cross- } \\ & \text { Sectional } \\ & \text { Quantitative }\end{aligned}$

Girasek E
2011 Cross-
sectional Quantitative sectional Quantitative

Kusurkar RA et al. 2010 Cross-
2009 Cross- Sectional Mixed methods

Singapore 192

192
- Humanitarian - Altruistic motivation

- Scientific - Gaining a degree,

- Finding a job,

- Accessing career opportunities.

- Scientific - Intellectual curiosity

- Societal - Personal illness / or

death of family members

- social prestige

- financial gain

- Scientific - Desire to help others

- Societal - Interest in medical subjects

Amsterdam 96 - Scientific • Research opportunities

- Humanitarian - Interest in subject

- Societal - Loss of loved one

- Opportunities to travel/work abroad

- Contact with people

- Scientific $\quad$ desire to help others

- Humanitarian - an affinity for science and - enjoying interacting with others

Hungary $560 \quad \cdot$ Scientific $\quad \cdot$ General interest

- Humanitarian · Intellectual work

- Helping profession

- Social utility

Netherland 620 • Scientific • Higher age

- Pre-entrance educational background

- Scientific

- interesting challenging job

- Societa

prefily encouragement

- prefer to study overseas 
Table 3 Factors affecting motivations of medical students to select medicine across different country income groups (Continued)

\begin{tabular}{|c|c|c|c|c|c|c|c|c|}
\hline S. No & Name of the study & Name of author & Year & Type of study & $\begin{array}{l}\text { Place of } \\
\text { study }\end{array}$ & $\begin{array}{l}\text { No. of } \\
\text { participants }\end{array}$ & $\begin{array}{l}\text { Factors } \\
\text { categorization }\end{array}$ & Individual factors \\
\hline 12. & $\begin{array}{l}\text { A two factor model of } \\
\text { performance approach } \\
\text { goals in student } \\
\text { motivation for starting } \\
\text { medical school. }\end{array}$ & Wilson J & 2009 & $\begin{array}{l}\text { Cross- } \\
\text { Sectional } \\
\text { Quantitative }\end{array}$ & West Indies & 180 & $\begin{array}{l}\text { - Humanitarian } \\
\text { - Societal }\end{array}$ & $\begin{array}{l}\text { - wanting to help people } \\
\text { - being respected and } \\
\text { successful } \\
\text { - fulfilling a sense of } \\
\text { achievement. }\end{array}$ \\
\hline 13. & $\begin{array}{l}\text { Why people apply to } \\
\text { medical school: } \\
\text { implications for } \\
\text { widening participation } \\
\text { activities. }\end{array}$ & McHarg J et al. & 2007 & $\begin{array}{l}\text { Cross } \\
\text { Sectional } \\
\text { Qualitative }\end{array}$ & $\begin{array}{l}\text { United } \\
\text { Kingdom }\end{array}$ & 15 & $\begin{array}{l}\text { - Scientific } \\
\text { - Humanitarian }\end{array}$ & $\begin{array}{l}\text { - desire to help people } \\
\text { - desire for gainful } \\
\text { employment } \\
\text { - wish to give something to } \\
\text { mankind } \\
\text { - desire to save lives } \\
\text { - to fulfil their lifelong } \\
\text { ambition }\end{array}$ \\
\hline 14. & $\begin{array}{l}\text { Comparison of Career } \\
\text { Choice Motivation and } \\
\text { Moral Reasoning Ability } \\
\text { between Students in } \\
\text { Baccalaureate and } \\
\text { Graduate-entry } \\
\text { Programs. }\end{array}$ & Kim MK & 2007 & $\begin{array}{l}\text { Cross- } \\
\text { Sectional } \\
\text { Quantitative }\end{array}$ & Korea & & $\begin{array}{l}\text { - Scientific } \\
\text { - Humanitarian } \\
\text { - Societal }\end{array}$ & $\begin{array}{l}\text { - Scientific interest } \\
\text { - Opportunities to care for } \\
\text { people } \\
\text { - Status } \\
\text { - Job security }\end{array}$ \\
\hline 15. & $\begin{array}{l}\text { Demographics and } \\
\text { motives of medical } \\
\text { school applicants in } \\
\text { Croatia. }\end{array}$ & Puljak L et al. & 2007 & $\begin{array}{l}\text { Cross- } \\
\text { Sectional } \\
\text { Quantitative }\end{array}$ & Croatia & 567 & $\begin{array}{l}\text { - Societal } \\
\text { - Scientific }\end{array}$ & $\begin{array}{l}\text { - Love for medical profession } \\
\text { - Humanity of medicine } \\
\text { - Interest in human body } \\
\text { structure and function } \\
\text { Interest in science } \\
\text { - An opportunity to work/ } \\
\text { interact with people }\end{array}$ \\
\hline 16. & $\begin{array}{l}\text { The attractions of } \\
\text { medicine: the generic } \\
\text { motivations of medical } \\
\text { school applicants in } \\
\text { relation to demography, } \\
\text { personality and } \\
\text { achievement }\end{array}$ & McManus IC et al. & 2006 & $\begin{array}{l}\text { Cross } \\
\text { Sectional } \\
\text { Quantitative }\end{array}$ & London & 2867 & $\begin{array}{l}\text { - Scientific } \\
\text { - Humanitarian } \\
\text { - Societal }\end{array}$ & $\begin{array}{l}\text { - Indispensibility } \\
\text { - Respect } \\
\text { - Helping others } \\
\text { - Science }\end{array}$ \\
\hline \multicolumn{9}{|c|}{ Upper middle income countries } \\
\hline 17. & $\begin{array}{l}\text { Achievement motivation } \\
\text { level in students of } \\
\text { Shiraz University of } \\
\text { Medical Sciences and its } \\
\text { influential factors. }\end{array}$ & $\begin{array}{l}\text { Kavousipour } S \text { et } \\
\text { al. }\end{array}$ & 2015 & $\begin{array}{l}\text { Cross - } \\
\text { Sectional } \\
\text { Quantitative }\end{array}$ & Iran & 770 & - Societal & $\begin{array}{l}\text { - family attitudes } \\
\text { - getting good jobs in future } \\
\text { - respect for themselves } \\
\text { - the ability to learn } \\
\text { - believing their role in } \\
\text { victory and defeat } \\
\text { - tendency toward optimism } \\
\text { about themselves }\end{array}$ \\
\hline 18. & $\begin{array}{l}\text { The characteristics of } \\
\text { medical students and } \\
\text { motivation towards } \\
\text { career choice } \\
\text { implications for } \\
\text { curriculum }\end{array}$ & Korkmaz H et al. & 2013 & $\begin{array}{l}\text { Cross- } \\
\text { Sectional- } \\
\text { mixed } \\
\text { methods }\end{array}$ & Turkey & 298 & $\begin{array}{l}\text { - Societal } \\
\text { - Humanitarian }\end{array}$ & $\begin{array}{l}\text { - Social status } \\
\text { - Responsible job } \\
\text { - High Income } \\
\text { - Helping others }\end{array}$ \\
\hline 19. & $\begin{array}{l}\text { Burnout and career } \\
\text { choice motivation in } \\
\text { medical students. }\end{array}$ & Pagnin D et al. & 2013 & $\begin{array}{l}\text { Cross- } \\
\text { Sectional } \\
\text { Quantitative }\end{array}$ & Brazil & 277 & $\begin{array}{l}\text { - Societal } \\
\text { - Scientific } \\
\text { - Humanitarian }\end{array}$ & $\begin{array}{l}\text { - Intellectual curiosity } \\
\text { - professional autonomy } \\
\text { - altruism } \\
\text { - interest in human } \\
\text { relationships }\end{array}$ \\
\hline 20. & $\begin{array}{l}\text { Factors Affecting Choice } \\
\text { of Specialty Among } \\
\text { First-year Medical } \\
\text { Students } \\
\text { of Four Universities in } \\
\text { Different Regions of } \\
\text { Turkey }\end{array}$ & Dikici FM et al. & 2008 & $\begin{array}{l}\text { Cross- } \\
\text { Sectional } \\
\text { Quantitative }\end{array}$ & Turkey & 717 & $\begin{array}{l}\text { - Societal } \\
\text { - Scientific }\end{array}$ & $\begin{array}{l}\text { - better financial } \\
\text { opportunities } \\
\text { - prestige } \\
\text { - personal development } \\
\text { - more benefits for the } \\
\text { patient } \\
\text { - wish to work in an urban } \\
\text { area }\end{array}$ \\
\hline
\end{tabular}


Table 3 Factors affecting motivations of medical students to select medicine across different country income groups (Continued)

\begin{tabular}{|c|c|c|c|c|c|c|c|c|}
\hline S. No & Name of the study & Name of author & Year & Type of study & $\begin{array}{l}\text { Place of } \\
\text { study }\end{array}$ & $\begin{array}{l}\text { No. of } \\
\text { participants }\end{array}$ & $\begin{array}{l}\text { Factors } \\
\text { categorization }\end{array}$ & Individual factors \\
\hline \multicolumn{9}{|c|}{ Lower Middle Income Countries } \\
\hline 21. & $\begin{array}{l}\text { Why become a doctor? } \\
\text { Evaluation of } \\
\text { motivational factors for } \\
\text { selecting medical } \\
\text { profession as a career }\end{array}$ & Kuriakose S & 2015 & $\begin{array}{l}\text { Cross } \\
\text { sectional } \\
\text { Quantitative }\end{array}$ & India & 100 & - Humanitarian & $\begin{array}{l}\text { - serve the poor and needy } \\
\text { - own interest. } \\
\text { - doctor in family. } \\
\text { - near ones suffering from } \\
\text { chronic illness or cancer, } \\
\text { - themselves suffering from } \\
\text { health problems } \\
\text { - influenced by the lack of } \\
\text { health care in rural areas. }\end{array}$ \\
\hline 22. & $\begin{array}{l}\text { Indian medical students } \\
\text { in public and private } \\
\text { sector medical schools: } \\
\text { are motivations and } \\
\text { career aspirations } \\
\text { different? - studies from } \\
\text { Madhya Pradesh, India }\end{array}$ & Diwan $\vee$ et al. & 2013 & $\begin{array}{l}\text { Cross - } \\
\text { Sectional } \\
\text { Quantitative }\end{array}$ & India & 792 & $\begin{array}{l}\text { - Humanitarian } \\
\text { - Societal }\end{array}$ & $\begin{array}{l}\text { - Personal choice } \\
\text { - Parent's wish } \\
\text { - Service } \\
\text { - Security } \\
\text { - Prestige }\end{array}$ \\
\hline 23. & $\begin{array}{l}\text { Why become a Doctor? } \\
\text { Exploring the Career } \\
\text { Aspirations and } \\
\text { Apprehensions among } \\
\text { Interns in South India }\end{array}$ & $\begin{array}{l}\text { Seetharaman N } \\
\text { et al. }\end{array}$ & 2012 & $\begin{array}{l}\text { Cross- } \\
\text { Sectional } \\
\text { Quantitative }\end{array}$ & South India & 147 & $\begin{array}{l}\text { - Humanitarian } \\
\text { - Societal } \\
\text { - Scientific }\end{array}$ & $\begin{array}{l}\text { - Personal interest \& passion } \\
\text { for the profession } \\
\text { - financial stability } \\
\text { - parents' wish }\end{array}$ \\
\hline 24. & $\begin{array}{l}\text { Career Aspirations and } \\
\text { Apprehensions } \\
\text { Regarding Medical } \\
\text { Education Among First } \\
\text { Year Medical Students } \\
\text { in Delhi }\end{array}$ & Lal P et al. & 2007 & $\begin{array}{l}\text { Cross- } \\
\text { Sectional } \\
\text { Quantitative }\end{array}$ & India & 189 & $\begin{array}{l}\text { - Humanitarian } \\
\text { - Societal }\end{array}$ & $\begin{array}{l}\text { - serve the sick and society } \\
\text { - high status of a doctor in } \\
\text { the society } \\
\text { - father's will } \\
\text { - to earn money and } \\
\text { - mother's will }\end{array}$ \\
\hline
\end{tabular}

In low-middle income countries, students are still striving to fulfill primary basic needs and safety and security of employment, family, health. They fall under the first two segments of the pyramid comprising of basic needs, safety stability and protection and hence the predominant motivational factors are humanitarian in this group. In some areas where these needs are fulfilled, the higher segment of self-esteem also come into picture, hence societal factors are also seen in lower-middle income countries. The prime reasons for selecting medical studies among students in low-income countries were parental desire, respected profession and economic incentives, respect in society, high societal status and to serve the sick. The desire to serve the poor is deeply ingrained in this society.

Table 4 Most commonly cited motivational factors among all the studies analyzed $(N=24)$

\begin{tabular}{llll}
\hline & Motivational factors & Number of Sudies & Percentage of studies \\
\hline Scientific factors & & 16 & 66.7 \\
1. & Interest in Medicine & 6 & 25 \\
2. & Professional growth/challenging career & 3 & 12.5 \\
3. & Work independence & 3 & 12.5 \\
4. & Work abroad/urban areas & & 75 \\
Humanitarian factors & & 18 & 12.5 \\
5. & Work for people/help underprivileged & 3 & 33.3 \\
6. & Family experience of a disease/death & & 25 \\
Societal factors & & 8 & 20.8 \\
7. & Social status/Prestige & 6 & 20.8 \\
8. & Financial security & 5 & 8.3 \\
9. & Job Security & 5 & 2 \\
10. & Parental wish & Family Tradition & 2 \\
\hline
\end{tabular}


Most of the students belong to lower or middle socioeconomic groups and understand the miseries of poor well and these factors lead them to serve the humanity and poor people. Here medical students are more sensitive to the social needs of population. The very reasons identified to take up medical career in these countries can be used to encourage students to take up medical studies. Mainly, the respect and feeling of altruism, followed by the monetary and social benefits are a driving force that can be used to attract the students into medical profession, hence improving the workforce. As the motivational factors are mostly innate, their further interest in medical studies and serving the nation will remain significant.

In the upper-middle income countries the factors as described by the middle zone in the Maslow's hierarchy of needs pyramid were identified. The majority of studies identified societal factors as better predictors as compared to humanitarian and scientific factors. The main motivators to select medicine by medical students of upper-middle income countries are job security, social status, and parental wish. The reason behind this is that, to become a doctor is one of the highest ambition of many school-going students and their parents in middle- and low-income countries, along with the fact that the medical profession is preferred by the students due to its high prospect of financial security and high social status. Being a respected profession with high social status and higher salaries has been found to be motivating factor for students. The students in these countries have mostly met their basic needs and are more attracted towards a better lifestyle and income. Security in all fronts is a strong predictor for picking medical studies, and this can help enroll more students into this career. Excelling in their medical education may act as a strong target as their competition decides their future prospects.

The motivational factors commonly reported by most of the studies in high-income countries were the third and fourth segments of the Maslow's hierarchy of needs pyramid. The scientific factors were the main motivators to select medicine by students. This may be due to the fact that the students in high-income countries chose medicine or science, who have prime interest in these subjects. The interest in science is usually developed during their school times to become medical school academics in a welldeveloped education system and with advanced technologies (modern laboratory facilities). The availability of good technologies and advanced education helps in developing specialized skills through the medical school years and beyond. In addition, the ability to earn well, pay their debts and live comfortably are strong motivators as well.

There are various strengths of the study. Firstly, the review was done on a sizeable number of 24 studies across the globe, hence generating stronger evidence. Secondly, the study relates the motivational factors across different countries with the Maslow's hierarchy of needs theory
[38]. This helps to understand the motivational factors of medical students to work in rural areas with respect to the innate motivational factors of a human being.

This review has a few limitations. Despite our efforts to identify all relevant studies by searching four different databases and using a fairly large number of search terms, we might have missed relevant studies. Additionally, unpublished studies from low- and middle-income countries were not represented (publication bias). The exclusion of articles published before 2006 may have omitted literature that could have provided valuable information. However, our review supplement two existing reviews published earlier $[8,9]$.

\section{Conclusion}

In conclusion, this systematic review investigated the reasons that affect students' decisions to join medical profession. The motivational factors are being classified in scientific factors (e.g. 'interest in medicine'), societal factors (e.g. 'respect/prestige') and humanitarian factors (e.g.'desire to help others'). The predominance of factors varied among students in high-, upper-middle and lower-middle income countries. Hence, this study offers cues to policy makers and educators in different countries to understand the motivational factors as a first step to formulate policy in order to tackle the shortage of health workers to improve the status of human resources across nations. However, more research on the subject would assist in promoting as well as translating health policy into concrete and effective measures at the local, national, regional and global levels in low- and middle- income countries.

\section{Abbreviations \\ MSMS: Motivation of selection of Medical Study; PRISMA: Preferred Reporting Items for Systematic Reviews and Meta-Analyses; WHO: World Health Organization}

\section{Acknowledgements \\ None. \\ Funding \\ This study did not receive any funding.}

\section{Availability of data and materials}

The datasets generated and analysed during the current study are available from the corresponding author on reasonable request.

\section{Authors' contributions}

Conceptualization: SG FA. Data curation: SG ND NS. Formal analysis: SG ND NS. Funding acquisition: SG. Investigation: SG. Methodology: SG FA DR. Project administration: SG. Resources: SG. Software: NS, ND. Supervision: SG. Validation: SG ND. Writing original draft: ND NS. Writing review \& editing: SG FA DR. All authors have read and approved the final version of the manuscript.

\section{Ethics approval and consent to participate}

The study was granted ethical approval from the Institute's Ethical Committee, PGIMER, Chandigarh (PGI/IEC/2012/810-1 P-154). The anonymity and confidentiality of participants in the studies were ensured. Since the study is a systematic review of studies and individual level data is not obtained, the consent was not required. 


\section{Consent for publication}

Since individual level data is not presented, the consent for publication of data was not required

\section{Competing interests}

The authors declare that they have no competing interests.

\section{Publisher's Note}

Springer Nature remains neutral with regard to jurisdictional claims in published maps and institutional affiliations.

\section{Author details}

${ }^{1}$ School of Public Health, PGIMER, Sector-12, Chandigarh 160012, India. ${ }^{2}$ Department of Health Services Research, Care and Public Health Research Institute, Faculty of Health, Medicine and Life Sciences, Maastricht University, Maastricht, The Netherlands. ${ }^{3}$ Department of Organization Studies, School of Social and Behavioural Sciences, Tilburg University, Tilburg, the Netherlands. ${ }^{4}$ Department of Health Services Research, Care and Public Health Research Institute, Faculty of Health, Medicine and Life Sciences, Maastricht University, Maastricht, The Netherlands.

\section{Received: 12 May 2017 Accepted: 9 January 2018}

\section{Published online: 17 January 2018}

\section{References}

1. World Health Organization. The world health report 2006: working together for health. Geneva: WHO; 2006 [Internet]. 2015. Available from: http://www. who.int/whr/2006/en/. Accessed 12 Oct 2015.

2. Smith MK, Henderson Andrade N. Facing the health worker crisis in developing countries: a call for global solidarity. Bull World Heal Organ. 84(6):425-504

3. Campbell J, Dussault G, Buchan J, Pozo-Martin F, Guerra Arias M, Leone C, Siyam A, Cometto G. A universal truth: no health without a workforce. Forum Report, Third Global Forum on Human Resources for Health, Recife, Brazil. Geneva: Global Health Workforce Alliance and World Health Organization; 2013

4. Rao K, Bhatnagar A, Berman P. India's health workforce: size, composition and distribution. In: La Forgia KR J, editor. India health beat. New Delhi: World Bank; New Delhi and Public Health Foundation of India; 2009.

5. Hurst SA. Eroding students' rural motivation: first do no harm? Swiss Med Wkly. 2014;144

6. Lambrou P, Kontodimopoulos ND. Motivation and job satisfaction among medical ; and nursing staff in a Cyprus public general hospital. Hum Res Health. 2010;8:26.

7. Kusurkar RA, Ten Cate TJ, Van Asperen M, Croiset G. Motivation as an independent and a dependent variable in medical education: a review of the literature. Med Teach. 2011;33(5):e242-62.

8. Puertas EB, Arósquipa C. Factors that influence a career choice in primary care among medical students from high-, middle-, and low-income countries: a systematic review. Rev PanamSalud Publica. 2013;34(5):351-8.

9. Brissette A, Howes D. Motivation in medical education: a systematic review. Web Med Central Med Educ. 2010;1(12):WMC001261.

10. The Sustainable Development Goals Report. Department of Economic and Social Affairs (DESA). New York: United Nations Publications; 2017.

11. Monitoring the building blocks of health systems: a handbook of indicators and their measurement strategies. Geneva: World Health Organization; 2010.

12. Egger $M$, Smith $D G$, Altman DG, ediors. Systematic reviews in health care: meta-analysis in context. 2nd ed. UK: BMJ Publishing Group; 2008.

13. Goel S, Angeli F, Singla N, Ruwaard D. Development and validation of the motivations for selection of medical study (MSMS) questionnaire in India. PLoS One. 2016;11(12):e0164581.

14. Bank TW. The World bank. World bank country and lending groups [internet]. [cited 16 Jan 2017]. Available from: https://datahelpdesk. worldbank.org/knowledgebase/articles/906519-world-bank-country-andlending-groups.

15. Győrffy Z, Birkás E, Sándor I. Career motivation and burnout among medical students in Hungary-could altruism be a protection factor? BMC Med Educ. 2016;16(1):182

16. Kim KJ, Hwang JY, Kwon BS. Differences in medical students' academic interest and performance across career choice motivations. Int J Med Educ. 2016;7:52.
17. Gąsiorowski J, Rudowicz E, Safranow K. Motivation towards medical career choice and future career plans of polish medical students. Adv Heal Sci Educ. 2015;20(3):709-25.

18. Sulong S, McGrath D, Finucane P, Horgan M, O'Flynn S, O'Tuathaigh C. Studying medicine-a cross-sectional questionnaire-based analysis of the motivational factors which influence graduate and undergraduate entrants in Ireland. JRSM open. 2014;5(4):2042533313510157.

19. Wouters A, Bakker AH, van Wijk IJ, Croiset G, Kusurkar RA. A qualitative analysis of statements on motivation of applicants for medical school. BMC Med Educ. 2014;14(1):200.

20. Laurence CM, Zajac IT, Turnbull DA, Sumner KE, Fleming J. Applicants to the University of Adelaide medical school: influences, motivation and alternative career choices. Focus Heal Prof Educ A Multi-disciplinary J. 2013;14(2):81.

21. Toso A, Ayala MJ, Brunner V, Rodriguez J, Hernández MI, Urquidi C, et al. Interests and perspectives of first and last year medical students. Rev Med Chil. 2012;140(5):609-15.

22. Girasek E, Molnár R, Eke E, Szócska M. The medical career choice motivations_-results from a Hungarian study. Open Med. 2011;6(4):502-9.

23. Kusurkar R, Kruitwagen C, ten Cate $O$, Croiset $G$. Effects of age, gender and educational background on strength of motivation for medical school. Adv Heal Sci Educ. 2010;15(3):303-13.

24. Amin Z, Tani M, Hoon Eng K, Samarasekara DD, Huak CY. Motivation, study habits, and expectations of medical students in Singapore. Med Teach. 2009:31(12):e560-9.

25. Wilson $\mathrm{Jl}$. A two factor model of performance approach goals in student motivation for starting medical school. Issues Educ Res. 2009:19(3):271-81.

26. Kim MK, Kang JO. Comparison of career choice motivation and moral reasoning ability between students in baccalaureate and graduate-entry programs. Korean J Med Educ. 2007;19(2):91-9.

27. Puljak L, Kraljevic JB, Latas VB, Sapunar D. Demographics and motives of medical school applicants in Croatia. Med Teach. 2007;29(8):e227-34.

28. McManus IC, Livingston $\mathrm{G}$, Katona $\mathrm{C}$. The attractions of medicine: the generic motivations of medical school applicants in relation to demography, personality and achievement. BMC Med Educ. 2006;6(1):11.

29. Becker JC, Burghaus D, Kappe K, Heue M, Liebelt A, Kindler Röhrborn BP A. No title. Dtsch Med Wochenschr. 2015;140(21):e207-16.

30. Kavousipour S, Noorafshan A, Pourahmad S, Dehghani-Nazhvani A Achievement motivation level in students of Shiraz University of Medical Sciences and its influential factors. J Adv Med Educ Prof. 2015:3(1):26.

31. Korkmaz H, Şenol YY. The characteristics of medical students and motivation towards career choice: implications for curriculum. Hacettepe Üniversitesi Eğitim Fakültesi Derg. 2013;28:28-1.

32. Pagnin D, De Queiroz V, De Oliveira Filho MA, Gonzalez NVA, Salgado AET, Oliveira BCE, et al. Burnout and career choice motivation in medical students. Med Teach. 2013;35(5):388-94.

33. Fevzi Dikici M, Yaris F, Topsever P, Muge Filiz T, Serdar Gurel F, Cubukcu M, et al. Factors affecting choice of specialty among first-year medical students of four universities in different regions of Turkey. Croat Med J. 2008;49(3):415-20.

34. Kuriakose S, Revankar SKB, Viveka S, Shetty B, Rao CP. Why become a doctor? Evaluation of motivational factors for selecting medical profession as career. Engineer. 2015;16(14):30.

35. Diwan V, Minj C, Chhari N, De Costa A. Indian medical students in public and private sector medical schools: are motivations and career aspirations different?-studies from Madhya Pradesh, India. BMC Med Educ. 2013;13(1):127.

36. Seetharaman N, Logaraj M. Why become a doctor? Exploring the career aspirations and apprehensions among interns in South India. Natl J Res Community Med. 2012;1(4):188-95.

37. Lal P, Malhotra C, Nath A, Malhotra R, Ingle GK. Career aspirations and apprehensions regarding medical education among first year medical students in Delhi. Indian J Community Med. 2007;32(3):217.

38. Maslow AH. Maslow's hierarchy of needs. Psychol Rev. 1943:50:370-96.

39. Asperoni G. Motivation, teamwork and agile development. Agile Times. 2004. Available at https://www.researchgate.net/publication/229037802 Motivation_teamwork_and_agile_development. Accessed 12 Jan 2018. 